УДК 101.1

DOI 10.35423/2078-8142.2019.3-4.10

Н. Д. Узунова, магістр філософії КНУ ім. Т. Г. Шевченка e-mail: natalya.uzunova@outlook.com ORCID: https://orcid.org/0000-0002-4755-0216

\title{
ФІЛОСОФІЯ МОВИ (ФРАНСУА РЕКАНАТІ) ТА ТЕОРІЯ ПОЕТИКИ (ЮЛІЯ КРІСТСВА): АКТУАЛІЗАЦІЯ СПІЛЬНИХ ПРОБЛЕМ ТА ПОШУКИ ЄДИНОГО ОСЕРЕДКУ
}

Стаття являє собою дослідження у сфері природної мови (та мови поетичної) і репрезентує певні спільні аспекти, які містяться у праиях Франсуа Реканаті та Юлії Крістєвої, не зважаючи на наявні методологічні розбіжності. Зазвичай, дослідження з поетики відокремлюють власний предмет від предмета аналізу лінгвістичного, зокрема, та - природної мови загалом, оскільки поетичній мові притаманні особливі властивості. Проте автор виходить із переконання, щу між дослідженнями текстів художніх творів, попри їхню складну семантику, та виразів природної мови є можсливим плідний консенсус. Подібне переконання, щуо випливає зі співставлення певних фрагментів вчень та понять Крістєвої і Реканаті, дає можливість вгледіти парадоксальну подібність предметів їхніх досліджень або спечифіки їхнього опису. Так, розгляд Реканаті, приміром, індексальних виразів не лише не суперечить концепту наративної темпоральності Крістєвої, а й відсилає до єдиного осередку (чи то зазнаваного впливу) підходів, щзо зумовлює иікавість не так до тексту або виразу, як до фігури мовия. У даному випадку за спільне впливове джерело покладається вчення Ж. Лакана, хоча автор і не вдається до розгорнутого розгляду такої думки, щзо потребує окремого трунтовного дослідження. Проте згадувані у статті теоретичні положення (принаймні, щодо статусу мовия) названих авторів можуть мати сенс у випадку спільного використання як у річищі поетики, так і відносно аналізу виразів природної мови. У иьому сенсі наголос ставиться на використанні теоретичних розробок Крістєвої та Реканаті з погляду зв'язку між ними, що дає можливість обопільно розширити горизонти дослідження мови як такої поза конкретних форм ї̈ репрезентації. 
Ключові слова: фено-текст, гено-текст, семіотичний диспозитив, інтертекст, хора, індексалії, контекст висловлювання, ментальна репрезентація.

Методи аналізу мови, у будь-якому її прояві, після «лінгвістичного повороту» набули колосальної розгалуженості, проте навіть найвіддаленіші з них можуть мати спільне коріння і за своєю природою зводитись до подібних не лише актуалізацій, а й до подібних засад, за відсутності знання про які та чи інша установка буде неточною. Наше дослідження присвячене пошуку спільних основ у проектах, відповідно, аналітичному - презентованому сучасним французьким дослідником Франсуа Реканаті, та поетики, що запропонований у ранніх працях французької дослідниці Юлії Крістєвої. Ці проекти є об’єктом даного дослідження, яке ставить проблему пошуку єдності між методологічно віддаленими аналізами мови.

Метою статті є обгрунтування, по-перше, близькості поглядів Ф. Реканаті та Ю. Крістєвої, по-друге, прокладання шляху до розширення меж аналізу як тексту художнього твору, так і мови природної. Реалізація мети передбачає конкретні завдання: виявити загальні проблематики, властиві досліджуваним авторам, та прослідкувати їх вирішення, що здійснюється у межах різних методів; вказати на те, яким чином спільні впливи визначають, попри наявні відмінності, певні загальні установки, що зумовлюють не лише більш повне відтворення названих проектів, а й можливу між ними взаємодію.

Ю. Крістєва ті Ф. Реканаті є представниками різних філософських традицій i, варто відзначити, зазнали впливу 3 різних джерел: Крістєва - впливу М. Бахтіна та соціологічного літературознавства як критики формалізму, Реканаті - впливу аналітичної філософії, насамперед Дж. Остіна. Проте є один загальний вплив, який у працях Реканаті, звісно, не такий яскравий, як у Крістєвої, але все ж присутній: Ж. Лакан (Крістєва і Реканаті протягом кількох років брали участь у Лаканівських семінарах). I ми спробуємо показати подібну сумісність, зіставивши спільні проблематики у їхній репрезентації з точки зору різних методів (до того ж стосовно різних вимірів мовленнєвої діяльності, відповідно, у першому ви- 
падку - поетики, адже Ю. Крістєва не є дослідником «langage ordinaire», а виключно «langage poetique», у другому - природної мови взагалі), що дають різні результати, але мають схожий осередок.

Перше, на що треба звернути увагу, це значний інтерес як Ю. Крістєвої (La révolution du langage poetique. L’avant-garde à la fin du XIX siècle Lautreamon et Mallarme, Paris, 1974), так i Ф. Реканаті (La transparence et l'énonciation, Paris, 1979; Philosophie du langage (et l'esprit), Paris, 2008; Truth-Conditional Pragmatics, Oxford, 2010) до визначення статусу суб'єкта мовлення/письма, без якого не $\epsilon$ можливим аналіз ні тексту художнього твору, ні сутності та функціонування природної мови.

У даному сенсі, якщо враховувати подібний інтерес до сутності, діяльності та самовисловлення суб'єкта, то першою чергою цікавими є розробки Ф. Реканаті у сфері визначення поняття індексальних виразів та їхнього співвідношення 3 контекстом висловлення (дане поняття згаданий автор тлумачить наступним чином: «той факт, що мовець говорить саме у даному своєму положенні, у даний момент, у певному конкретному місці... створює контекст або ж ситуацію висловлювання» [6, с. 36]. «У даному випадку контекст має дві форми: реальний і той, що імітується» («... оповідач висловлюється у тому контексті, що імітується, і тим відрізняється від автора, який продукує дійсний текст у контексті реальному», тобто у першому випадку «... робиться вигляд, що мова проговорюється» $[5$, с. 16]).

Ідея інтертексту Крістєвої (що розуміється як «пермутація текстів, де перехрещуються та нейтралізують одне одного кілька висловлювань, взятих із різних текстів» $[2,136])$ узгоджується 3 контекстом, що імітується, оскільки певною мірою паралель, яку ми проводимо між даною дистинкцією контексту та наявністю об'єктного та прямого слова, що формують інтертекстуальну площину художнього твору (точніше, виразів, що проговорюються носіями об'єктного та прямого слова), натикаються, якщо базуватись на поглядах Крістєвої, на експансію мови об'єктної прямою мовою, отже, контексту реального - тим, що імітується. У цьому випадку увага зміщується на того, хто проговорює, проте не варто забувати, що Крістєва приписує прямому слову трансгресивну 176

Institute of Philosophy of H. S. Skovoroda of NAS of Ukraine 
якість, яка порушує його цілісність, тому тут промовляння/письмо опосередковане «чужим словом», цитатою, переказом, є введенням в інтенцію мовця інтенції того, що ми називаємо Чужим - він порушує єдність тінню іншого сенсу, іншої ідеології, даної через «голоси» оживаючого художнього тексту.

Щоб загострити цей момент, Крістєва вводить поняття «семантичний диспозитив», що займає проміжне місце між генотекстом (гено-текст - передвербальна бесструктурність, основа сенсотворення на до-мовному рівні $[4$, с. 83]: «Те, що ми можемо назвати гено-текстом (un géno-texte), охоплює всі семіотичні процеси (імпульси, їхній порядок, слід, який вони залишають на тілі, на системі екологічній та соціальній, що оточують організм: найближчі об'єкти, перед-едипові відносини з батьками), а також становлення символічного (прояв суб'єкта, створення осередків сенсу, які залежать від семантичної та категоріальної площин)» і фенотекстом (фено-текст (un phéno-texte) - це структура, яка підпорядковується правилам зовнішньої комунікації, що передбачає також адресата акту висловлювання [4, с. 85]: «численні примуси - першою чергою, соціально-політичне замовлення - гальмують процес означення у тому чи іншому аспекті, якого це замовлення стосується... фено-текст вміщає все загальмоване...»), де «утримуються порушення фонетичні, лексичні, синтаксичні і водночас стають наявними» [4, с. 86] - це той переломний етап, коли виявляється, що для занурення у світ мови потрібна відмова від свого «голосу» носієм об'єктного слова.

Не зважаючи на дистинкцію контекстів, Реканаті не розглядає можливості трансгресивних наслідків, по-перше, по-друге - не розглядує можливість впливу на інтенцію мовця, на можливість іiі викривлення. Він виходить 3 дещо інакших міркувань, розмежовуючи параметри дискурса на контрольовані та неконтрольовані. Перші - «те, значення чого він (мовець) може змінити» - включають демонтсративи, які можуть бути будь-якими залежно від спрямованості, та безпосередньо адресата («...деякі «ти») або «інтерлокутера», як його іменує Реканаті, який також може варіювати, тобто залежить від іншої персони - персони мовця. Другі - тут «той, хто висловлюється не є вільним фіксувати дискурс на рівні контекстуальних параметрів» - включає конкретне місце та час 
висловлювання, а також ідентичність мовця, що зумовлена референцією «я» [5, с. 17].

Це не суперечить міркуванням Крістєвої, адже будь-який художній текст припускає власну топіку та часовість оповіді, які в межах того, що Реканаті іменує контекстом, який імітується, котрі зумовлюють гетерогенність тексту, будучи зіставленими зі сукупністю вказівок на певне «тут» та «у цей момент». Проте референція, притаманна художньому твору, має суттєву відмінність - вона не стосується конкретних предметів, а відсилає або до іншого тексту, або до будь-якого безпредметного поняття, по-перше. Подруге, по суті будь-яка топіка та часовість художнього тексту проявляється разом (з причини своєї безпредметності, поза-тілесності) зі словом Чужого, стаючи не більше, як далекою та ніколи не досягненою Ітакою. Тому достатньо залучити ідею наративної темпоральності. Реканаті також займає проблема зіставлення теперішнього та минулого часу у висловлюванні, хоча він вирішує ії інакше, не сходячи до нескінченного сьогодення.

У цьому відношенні Реканаті використовує ще один розподіл розуміння контексту на зовнішній, «... який дає можливість розрізнення та відношення індексалій... він є даним об'єктивно і не залежить від комунікаційних інтенцій» та внутрішній, «... який формується самим висловлюванням» [5, с. 21]. Тому дещо, що переповідається (тобто оповідь взагалі з іi напластуванням можливих умов «тут і тепер»), хоч і стає актуальним тільки у теперішньому часі, однак передбачає розмежування на рівну статусу контексту часу теперішнього та минулого, якого оповідь стосується, тобто минуле, стаючи теперішнім, все ж таки залишається минулим (щодо статусу у висловлюванні чи то у тексті художнього твору часу майбутнього не йдеться ні у Реканаті, ні у Крістєвої, оскільки дана проблема стосується сфери визначення пресуппозиції, по-перше, по-друге - майбутній час художнього твору не передбачає дійсного вказування на можливість наявності оповіді через певний проміжок часу).

Якщо взяти до уваги ідею наративної темпоральності, про яку йдеться у Ю. Крістєвій (згідно з якою оповідь завжди оживає у теперішньому часі, де суб'єкт розповіді мислить себе завжди вже суб'єктом висловлювання, що прив'язує розповідь до вже готового 178

Institute of Philosophy of H. S. Skovoroda of NAS of Ukraine 
висловлювання, але не гарантує їх тотожності), то до вищесказаного можна застосувати поняття певної мета-темпоральності, що конструюється над інтертекстуальним простором, що має власний внутрішній часовий вимір, який мета-темпоральність не порушувала би. За тим самим принципом вірогідною стає нівеляція Чужого (як носія прямого слова) та «чужого слова» (як випадку цитування, якого неможливо уникнути у межах оповіді), що, за великим рахунком, стає можливим завдяки застосуванню поняття контр-тексту.

До того ж наявність у деяких висловлюваннях змішаних цитат для Реканаті не є проблемою пошуку їхнього прозорого, зрозумілого змісту - вони зберігають власну автономію, створюючи власний загальний контекстуальний сенс [7, с. 506], що є результатом залучення принципу композиційності, де значення висловлення $є$ функцією його компонентів та їхнього синтаксичного співвідношення [8, с. 240].

I тут ми підходимо до відкриття загального впливу. У Крістєвої спостерігається така картина: лексичні та семантичні утворення мають подвійний характер. 3 одного боку, вони - результат функціонування семіотичного диспозитиву (un dispositif sémiotique) (тобто так чи інакше підпорядковуються правилам зовнішньої комунікації), а з іншого - у своєму початковому, не викривленому вигляді знаходяться під впливом хори (поняття Лакана, хоча вперше зустрічається у Платона), яка $є \ll . .$. не взірець, не відображення - вона передує будь-якому утворенню (тому - мисленню), можна провести аналогію хіба що 3 ритмом звучання чи доторку» [4, с. 23].

Не випадково одна 3 найвластивіших праць Реканаті має назву «Філософія мови (i духу)» (Philosophie du langage (et de l’esprit)). Дух розуміється у даному випадку, звісно, не у релігійному сенсі. Це екзистенція мовця, що являє себе у мовленнєвому акті. Для позначення даного процесу вводиться поняття «ментальна репрезентація», запропоноване Реканаті як явище розкриття мислення через мовленнєві акти (у семантичних структурах), що забезпечується інтенційністю самої свідомості [8, с. 239], хоча і не передбачає проміжку між імпульсами (бажаннями, намірами) мовця та наявними умовами, які з необхідністю потребують пертурба- 
ції об'єктної мови. Цей момент виводить за межі суто прагматики та змушує звернутись до досліджень суб'єкта мовлення та його довербальних засад, до підсвідомих пульсацій, що повертає до кола питань традиції франкомовної психолінгвістики. До того ж варто зазначити відносно сутності індексалій: Ф. Реканаті наголошує на тому, що їхнє визначення є можливим виключно через ту саму ментальність, яка не $\epsilon$ підпорядкованою та очевидною для аналізу лінгвістичного [6, с. 33].

У цьому сенсі особливо цікавим є питання, що так чи інакше порушується у межах аналітичної традиції (філософії мови), але не має стосунку до поетики та лінгвістики, - питання про істинність висловлювання. Воно залишається присутнім й у працях Ф. Реканаті, але набуває не зовсім класичного розв'язання. Так, один 3 його рецензентів повідомляє, що «він (Реканаті) здійснює дистинкцію між умовами істини «композиційної» (що є традиційним для логіки та філософії мови - чиста «семантика») та «інтуїтивної» (яка справді продукує умови міркування мовця щодо істини чи хиби певного висловлювання: вона визначається як «прагматика»)». Тобто можна твердити, що йдеться вже не про прагматику як «дослідження інтерпретації (або використання) носіями мов семантичних відношень» [1, с. 17], а про довербальний рівень психічного буття мовця, що зумовлює контекст, де стає можливим дійсне вирізнення істини чи хиби (власне, тому умови комунікації як такої розглядаються не як дещо зовнішне (деяка сукупність правил та норм), а як безпосередньо ментальні, довербальні), що знов повертає нас до психолінгвістики. I хоча трансгресивні процеси виключається, все ж таки передбачається подвійна структура мови, що оперує складовими: семантичною (зовнішньою) та ментальною (внутрішньою, психічною), саме це $є$ місцем перетину проектів Ю. Крістєвої та Ф. Реканаті та являє собою прояв єдиного впливу, який проковзує навіть крізь різність використовуваних методів аналізу мови.

Таким чином, по-перше, проект поетики Ю. Крістєвої та дослідження Ф. Реканаті, що грунтуються на різних методологічних засадах, мають у певному сенсі спільне ядро, наявність якого, у випадку Реканаті, не є властивим англо-американській традиції філософії мови, що змушує, відповідно, шукати інші можливі 180

Institute of Philosophy of H. S. Skovoroda of NAS of Ukraine 
впливи, до яких ми приходимо через зіставлення поняття ментальної репрезентації у тому значенні, яке цей термін набуває у працях згаданого автора, та поняттям «хора» (ії сутністю та функцією стосовно мовленнєвої діяльності/письма), що є запозиченим Крістєвою у первинному вигляді зі словника Ж. Лакана, до філософії якого був звернений інтерес як Реканаті, так і Крістєвої у ранній період їхнього дослідницького шляху. По-друге, на нашу думку, згадувані положення Реканаті можуть мати сенс для досліджень у річищі поетики. Це, наприклад, було б доречним щодо аналізу топіки та часових вимірів, які мають місце у тексті художнього твору, що відкривало б нові горизонти для подібного аналізу художньої літератури, оминаючи актуалізацію ідеї трансгресії та переходу до пошуку універсальності методу дослідження мови.

\section{ЛITEРАТУРА}

1. Алексюк А. I. Філософія мови: традиція аналітичної філософії. Методичні матеріали до лекційних тем спецкурсу (частина I). Київ : Такі справи, 2001.

2. Кристева Ю. Избранные труды: Разрушение поэтики. М. : Российская политическая энциклопедия, 2004.

3. Brabater $P$. Philosophes du langage et autonymie : une déjà longue hisnoire//Histoire Epistémologie Langage, 2005. V. 27/1.

4. Kristeva $J$. La révolution du langage poetique. L'avant-garde à la fin du XIX siècle. Lautreamon et Mallarme. Paris : Editions du Seuil, 1974.

5. François R. D'un contexte à l'autre. Paris : Presses de l'Ecole normale supérieure, 2006.

6. François $R$. Loana dans le métro. Remarques sur l'indexicalité mentale. Paris : Presses de l’Ecole normale supérieure, 2001.

7. François R. Truth-conditional Pragmatics. Oxford, 2010

8. Vallée $R$. Compte rendu: Recanati François. Philosophie du langage (et de l'esprit). Paris : Philosophiques, 2007. Vol. 37/1.

\section{REFERENCES}

1. Aleksiyk, A. (2001). Language Philosophy: The Tradition of Analytical Philosophy. Methodical materials for the lecture topics of the special course (part I). Kyiv: Taki spravy. [In Ukrainian]. 
2. Kristeva, J. (2004). Selected Works: The Destruction of Poetics. «Russian Political Encyclopedia». [In Russian].

3. Brabater, P. (2005). Philosophes du langage et autonymie: une déjà longue hisnoire. Histoire Epistémologie Langage, 27/1.

4. Kristeva, J. (1974). The revolution of poetic language. The avantgarde at the end of XIX century. Lautreamon and Mallarme. Paris: Editions du Seuil.

5. François, R. (2006). From one context to another. Paris: Presses de l'Ecole normale supérieure.

6. François, R. (2001). Loana in the subway. Notes on mental indexicality. Paris: Presses de l’Ecole normale supérieure.

7. François, R. (2010). Truth-conditional Pragmatics. Oxford.

8. Vallée, R. (2007). Report: Recanati François. Philosophy of language (and the mind). Paris: Philosophiques, 37/1.

\title{
Nataliia Uzunova
}

master of Philosophy, Taras Shevchenko National University of Kyiv, Kyiv, Ukraine, e-mail: natalia.uzunova@outlook.com ORCID: https://orcid.org/0000-0002-4755-0216

\section{Philosophy of language (François Recanati) and theory of poetics (Julia Kristeva): actualization of common problems and search for single center.}

\begin{abstract}
This article is a study of natural language (and poetic language) and represents some common aspects that we find in the works of François Recanati and Julia Kristeva, despite the existing methodological differences. As a rule, studies in the field of poetics separate their subject from the subject of linguistic analysis (in particular), as well as from the subject of analysis of natural language (in general), since the poetic language has specific features. However, the author of the article proceeds from the belief that a consensus is possible between studies of texts of artistic works, despite their complex semantics, and expressions of natural language. This belief is based on the comparison of some fragments of the teachings and concepts of Kristeva and Recanati, which allows us to see the paradoxical similarity of the subjects of their research. Thus, consideration of Recanati, for example, of index expressions, does not simply not contradict the concept of Kristeva's narrative temporality, but refers to the search for a common source (or influence) of approaches. This common source causes interest not so much to the text or expression as to the figure of
\end{abstract} 182

Institute of Philosophy of H. S. Skovoroda of NAS of Ukraine 
their author. In this case, as an influential source, the teaching of Lacan relies, although the author of the article does not develop this idea, which can become the basis of a separate study. However, the theoretical propositions that are mentioned in the article (at least with respect to the author of the text or expression) belonging to the philosophers under investigation may make sense in the case of joint use both in poetics and in the analysis of natural language. In this sense, the article emphasizes the use of Kristeva and Recanati developments in terms of the relationship between them. This will allow us to expand the horizons of the study of the language, regardless of the specific forms of its representation.

Keywords: pheno-text, geno-text, intertext, semiotic dispositif, chora, context statevent, mental representation.

\section{Наталия Узунова}

магистр, Киевский национальный университет им. Т. Г. Шевченко

г. Киев. Украина, e-mail: natalia.uzunova@outlook.com

ORCID: https://orcid.org/0000-0002-4755-0216

\section{Философия языка (Франсуа Реканати) и теория поэтики (Юлия Кри- стева): актуализация общих проблем и поиски единого основания.}

\section{Аннотация}

Данная статья представляет собой исследование в области естественного языка (и языка поэтического) и репрезентирует некоторые общие аспекты, находимые в работах Франсуа Реканати и Юлии Кристевой, несмотря на наличествуюшие методологические расхождения. Как правило, исследования по поэтике отделяют собственный предмет от предмета лингвистического анализа в частности, и естественного языка в целом, поскольку поэтическому языку присущи специфические особенности. Однако автор исходит из убеждения, что между исследованиями текстов художественных произведений, несмотря на их сложную семантику, и выражений естественного языка возможен плодотворный консенсус. Подобное убеждение исходит из сопоставления некоторых фрагментов учений и понятий Кристевой и Реканати, что позволяет усмотреть парадоксальное сходство предметов их исследований и специфики описаний. Так, рассмотрение Реканати, например, индексальных выражений не просто не противоречит концепту нарративной темпоральности Кристевой, но и отсылает к возможно общему истоку (или испь- 
танному влиянию) подходов, который обуславливает интерес не столько к тексту или выражению, сколько к фигуре их автора. В данном случае, $в$ качестве общего влиятельного источника полагается учение Ж. Лакана, хотя автор статьи и не развивает данную мысль, которая может стать основой отдельного исследования. Однако упоминаемые в статье теоретические положения (по крайней мере, в отношении автора выражения или текста) указанных философов могут иметь смысл в случае совместного использования как в русле поэтики, так и естественного языка. В этом смысле автор настаивает на использовании разработок Кристевой и Реканати с точки зрения связи между ними, что позволяет обоюдно расширить горизонты исследования языка как такового вне конкретных форм его репрезентации.

Ключевые слова: фено-текст, гено-текст, интертекст, семиотический диспозитив, хора, индексалии, контекст выражения, ментальная репрезентаичия. 